\title{
Vitamin D deficiency is a problem for adult out-patients? A university hospital sample in Istanbul, Turkey
}

\author{
Ozlem Cigerli ${ }^{1, *}+$, Hulya Parildar ${ }^{1}$, Asl $_{1}$ D Unal ${ }^{2}$, Ozlem Tarcin ${ }^{2}$, Rengin Erdal ${ }^{1}$ and \\ Nilgun Guvener Demirag ${ }^{2}$ \\ ${ }^{1}$ Faculty of Medicine, Department of Family Medicine, Baskent University, Ankara, Turkey: ${ }^{2}$ Faculty of Medicine, \\ Department of Endocrinology, Baskent University, Ankara, Turkey
}

Submitted 12 September 2011: Final revision received 1 April 2012: Accepted 14 June 2012: First published online 9 August 2012

\begin{abstract}
Objective: To investigate the frequency of vitamin D deficiency in relation to demographics, clinical diagnosis, season of measurement and laboratory parameters in adult out-patients.

Design: Descriptive, retrospective study concerning evaluation of the initial 25-hydroxyvitamin D (25(OH)D) levels determined at admission in relation to demographics, clinical diagnosis, season of measurement and laboratory parameters. 25(OH)D levels $<20 \mathrm{ng} / \mathrm{ml}$ were classified as deficiency, 20-30 ng/ml as insufficiency and $>30 \mathrm{ng} / \mathrm{ml}$ as sufficiency.

Setting: Out-patient clinics at a tertiary care centre.

Subjects: A total of 2488 adult patients (mean age: $53 \cdot 3$ (sD $15 \cdot 2$ ) years; $85 \cdot 2 \%$ were females) admitted to out-patient clinics at Baskent University Istanbul Hospital were included.

Results: Mean level of $25(\mathrm{OH}) \mathrm{D}$ in the overall population was $17 \cdot 4(\mathrm{sD} 11 \cdot 5) \mathrm{ng} / \mathrm{ml}$ while insufficiency and deficiency were evident in $24 \%$ and $66 \%$ of patients, respectively. Mean $25(\mathrm{OH}) \mathrm{D}$ levels in males $>45$ years old were higher than in their female counterparts $(19 \cdot 4(\mathrm{SD} 11 \cdot 3) \mathrm{ng} / \mathrm{ml} v .17 \cdot 8(\mathrm{SD} 12 \cdot 2) \mathrm{ng} / \mathrm{ml} ; P<0 \cdot 05)$. Mean 25(OH)D levels obtained in summer $(18 \cdot 6(\mathrm{SD} 11 \cdot 1) \mathrm{ng} / \mathrm{ml})$ and autumn $(23 \cdot 3(\mathrm{sD} 13 \cdot 6) \mathrm{ng} / \mathrm{ml})$ were significantly higher than levels in spring $(16 \cdot 1$ $(\mathrm{sD} 10 \cdot 3) \mathrm{ng} / \mathrm{ml})$ and winter $(14 \cdot 6(\mathrm{sD} 10 \cdot 2) \mathrm{ng} / \mathrm{ml} ; P<0 \cdot 01)$. Mean 25(OH)D levels were determined to be significantly lower in obese patients compared with non-obese patients $(15 \cdot 6$ (SD 10.4) ng/ml $v .17 \cdot 6$ (SD 11.6) ng/ml; $P<0 \cdot 05$ ). Levels of $25(\mathrm{OH}) \mathrm{D}$ were significantly negatively correlated with serum parathyroid hormone levels $(r=-0 \cdot 194 ; P<0 \cdot 001)$ while significantly positively correlated with phosphorus $(r=0 \cdot 059 ; P<0 \cdot 01)$ and HDL cholesterol $(r=0 \cdot 070 ; P<0 \cdot 01)$ levels. Conclusions: Our findings indicate that vitamin D deficiency is very common among out-patients in Turkey, regardless of gender and age, especially among obese people and during winter and spring.
\end{abstract}

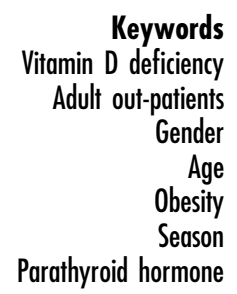

Owing to renewed scientific interest in vitamin $\mathrm{D}$ in relation to newly described benefits extending beyond healthy bones, several studies concerning the effects of vitamin $\mathrm{D}$ in many varying clinical conditions have been published in the previous decade ${ }^{(1)}$.

Either synthesized in the form of vitamin $\mathrm{D}_{3}$ (cholecalciferol) under the influence of solar UV-B radiation in the epidermis or absorbed from the diet or from supplements and food additives, which in some countries may contain vitamin $\mathrm{D}_{2}$ (ergocalciferol), vitamin $\mathrm{D}$ is transferred to the liver, where it is metabolized to 25-hydroxyvitamin D $(25(\mathrm{OH}) \mathrm{D})^{(2)}$. Since it denotes

$\uparrow$ Correspondence address: Baskent University Istanbul Hospital, Oymac1 sokak No. 7, 34662 Altunizade, Istanbul, Turkey. the sum of $25(\mathrm{OH}) \mathrm{D}_{3}$ and $25(\mathrm{OH}) \mathrm{D}_{2}$, the plasma level of this metabolite has been considered as the most stable, plentiful and reliable indicator of an individual's vitamin D status $^{(2)}$, reflecting the sum of vitamin D from endogenous synthesis and from dietary intake ${ }^{(1)}$.

Hypovitaminosis D is a global problem, prevalent across both genders and all age groups, even in sunny countries ${ }^{(3)}$. Using $25(\mathrm{OH}) \mathrm{D}$ cut-off values of $20 \mathrm{ng} / \mathrm{ml}$ to define deficiency and $30 \mathrm{ng} / \mathrm{ml}$ to define insufficiency in adults, it is estimated that one billion individuals have vitamin D insufficiency or deficiency worldwide ${ }^{(4,5)}$. There is growing evidence that vitamin D sufficiency is required for optimal health in general, and musculoskeletal health in particular ${ }^{(5,6)}$.

In this respect, once thought to be primarily a determinant of bone health, it is now recognized that 
vitamin $\mathrm{D}$ is a requisite hormone involved in a myriad of physiological processes including immune modulation, genetic regulation, hormone production and cellular functioning throughout the life cycle $e^{(2,7)}$.

Indeed, the requirement for vitamin $\mathrm{D}$ in a wide variety of essential biological functions such as bone and mineral metabolism, muscle function and immunity ${ }^{(8)}$ explains why many chronic diseases including osteoporosis and fractures, falls, cancer, psoriasis, diabetes mellitus, obesity, hypertension, multiple sclerosis, rheumatoid arthritis, inflammatory bowel disease and sixteen different cancer types $^{(4,9,10)}$ show significant negative associations with serum $25(\mathrm{OH}) \mathrm{D}$ as has been noted in a variety of populations $^{(8)}$.

Vitamin D deficiency is of particular interest because it is easily, safely and inexpensively corrected with adequate supplementation. Although findings have been somewhat inconsistent, trials of the effects of vitamin D supplementation suggest beneficial effects on important clinical outcomes ${ }^{(8)}$. As a result, increased attention has been directed at improving vitamin D nutrition, including recent recommendations to increase the routine intake of vitamin $\mathrm{D}^{(11)}$.

The present retrospective study was designed to investigate the prevalence of vitamin D deficiency in relation to patient demographics, clinical diagnosis, season of measurement and laboratory parameters, including levels of fasting blood glucose, glycated $\mathrm{Hb}$ (HbA1c), insulin, creatinine, $\mathrm{Ca}$, phosphorus, LDL cholesterol (LDL-C), HDL cholesterol (HDL-C), TAG, high-sensitivity C-reactive protein (hsCRP) and parathyroid hormone (PTH), in Turkish adult out-patients.

\section{Methods}

A total of 2488 adult patients (mean age: $53 \cdot 3$ (SD 15.2) years; $85 \cdot 2 \%$ were females) who were admitted to outpatient clinics at Baskent University Istanbul Hospital (total number of new patient admissions was 313779) from March 2009 to March 2011 were included in the present descriptive, retrospective study. Patients receiving therapeutic or prophylactic vitamin D supplement therapy were included in the study, while patients having a diagnosis of chronic renal failure or chronic liver failure and older than 75 years of age were excluded.

The initial 25(OH)D levels determined at admission were evaluated in relation to patient demographics, clinical diagnosis (according to the International Classification of Diseases, 10th revision), season of measurement and laboratory parameters including levels of fasting blood glucose $(\mathrm{mg} / \mathrm{dl})$, HbA1c $(\%)$, insulin $(\mu \mathrm{I} / \mathrm{ml})$, creatinine (mg/dl), Ca (mg/dl), phosphorus (mg/dl), LDL-C (mg/dl), HDL-C $(\mathrm{mg} / \mathrm{dl})$, TAG $(\mathrm{mg} / \mathrm{dl})$, hsCRP $(\mathrm{mg} / \mathrm{l})$ and PTH $(\mathrm{pg} / \mathrm{ml})$. Obesity was diagnosed by the clinician based on WHO criteria, which noted according to the International
Classification of Diseases, 10th revision, with consideration of obese and overweight patients under the 'obese' class as indicated by BMI values ${ }^{(12)}$. Serum 25(OH)D levels $<20 \mathrm{ng} / \mathrm{ml}$ were classified as deficiency, 20-30 ng/ml as insufficiency and $>30 \mathrm{ng} / \mathrm{ml}$ as sufficiency ${ }^{(4)}$.

\section{Assay of vitamin $D$ and otber laboratory parameters}

All instruments and kits were from Abbott Laboratories, Abbott Park, IL, USA. Serum 25(OH)D levels were measured with a chemiluminescent immunoassay method (Architect i1000 system); normal ranges were $15 \cdot 7-60 \cdot 3 \mathrm{ng} / \mathrm{ml}$ (summer) and $8 \cdot 8-46 \cdot 3 \mathrm{ng} / \mathrm{ml}$ (winter); and the intraassay $\mathrm{CV}$ ranged from $2 \cdot 6$ to $4 \cdot 0 \%$. Insulin levels were analysed by chemiluminescent immunoassay (Architect i1000 system); normal range $2 \cdot 6-24 \cdot 9 \mu \mathrm{U} / \mathrm{ml}$; intra-assay CV $2 \cdot 3-4 \cdot 2 \%$. Serum PTH levels were measured with an electrochemiluminescent immunoassay method (Architect i2000 system); normal range $15-68 \mathrm{pg} / \mathrm{ml}$; intra-assay $\mathrm{CV}$ $3 \cdot 0-6 \cdot 5 \%$. Levels of hsCRP were measured with an immunoturbidimetric assay (C8000 system); normal level $<0.5 \mathrm{mg} / \mathrm{dl}$; intra- and inter-assay CV $0.65-4.00 \%$ and $0 \cdot 26-2 \cdot 38 \%$, respectively. Serum Ca and phosphorus levels were measured with an enzymatic colorimetric assay (C8000 system); intra- and inter-assay CV were respectively $0 \cdot 5-0 \cdot 6 \%$ and $0 \cdot 3-0 \cdot 5 \%$ for $\mathrm{Ca}, 0 \cdot 5-0.5 \%$ and $0 \cdot 3-0 \cdot 6 \%$ for phosphorus. Serum glucose levels were measured by enzymatic colorimetric assay (C8000 system); intraand inter-assay CV were $0 \cdot 65-1.98 \%$ and $0 \cdot 84-0 \cdot 93 \%$, respectively. HbA1c was detected with a turbidimetric assay method (C4000, Architect cSystem); intra- and interassay CV were $0 \cdot 77-0 \cdot 88 \%$ and $1 \cdot 45-1 \cdot 88 \%$, respectively. Serum total cholesterol, TAG, HDL-C, LDL-C, creatinine, aspartate aminotransferase and alanine aminotransferase were measured by enzymatic colorimetric assay (C8000 system); the within-run and between-run $\mathrm{CV}$ were, respectively, $1 \cdot 1-1 \cdot 4 \%$ and $1 \cdot 92-2 \cdot 2 \%$ for TAG, $0 \cdot 4-1 \cdot 1 \%$ and $0 \cdot 2-0 \cdot 8 \%$ for aspartate aminotransferase, $0 \cdot 5-1 \cdot 5 \%$ and $0 \cdot 7-1 \cdot 3 \%$ for alanine aminotransferase; intra-assay and inter-assay CV were $1 \cdot 0-1 \cdot 7 \%$ and $0 \cdot 5-1 \cdot 1 \%$, respectively, for HDL-C.

\section{Etbical approval}

The study was approved by Baskent University Institutional Review Board (project no. KA11/167). The study protocol was approved by the institutional ethics committee of the Baskent University Faculty of Medicine.

\section{Statistical analysis}

Statistical analysis was conducted using the SPSS statistical software package version $16 \cdot 0$ (SPSS Inc.). Student's $t$ test and one-way ANOVA were used for the comparison of parametric variables. Pearson correlation analysis was performed to reveal the relationship of $25(\mathrm{OH}) \mathrm{D}$ levels with laboratory parameters. Data are expressed as mean and 
standard deviation or as number and percentage where appropriate. $P<0 \cdot 05$ was considered statistically significant.

\section{Results}

Mean age of the patients was $53 \cdot 3$ (SD 15.2) years. The percentage of female and male patients was $85 \cdot 2 \%$ ( $n$ 2131) and $14.9 \%$ ( $n$ 373), respectively. Female $(53 \cdot 3$ $(\mathrm{SD} 15 \cdot 2)$ years) and male $(53 \cdot 4$ (SD $15 \cdot 7)$ years) patients were homogeneous in terms of mean age. Clinical diagnoses at initial admission are listed in Table 1.

Mean level of $25(\mathrm{OH}) \mathrm{D}$ in the overall study population was $17 \cdot 4(\mathrm{sD} 11 \cdot 5) \mathrm{ng} / \mathrm{ml}$. There was no gender influence on $25(\mathrm{OH}) \mathrm{D}$ levels in the overall population and in patients $<45$ years of age; but, when patients $\geq 45$ years of age were considered, mean $25(\mathrm{OH}) \mathrm{D}$ levels were determined to be significantly higher in male patients than females $(P<0 \cdot 05$; Table 2$)$.

Season of $25(\mathrm{OH}) \mathrm{D}$ measurement is presented in Table 2. When mean 25(OH)D levels were compared with respect to the season of measurement, it was

Table 1 Clinical diagnoses at initial admission among adult outpatients (n 2488), Istanbul, Turkey, March 2009-March 2011

\begin{tabular}{lrr}
\hline Clinical diagnosis & $n$ & $\%$ \\
\hline Hypothyroidism and/or multinodular goitre & 1269 & $51 \cdot 0$ \\
Diabetes mellitus & 1138 & $45 \cdot 7$ \\
Hyperlipidaemia & 739 & $29 \cdot 7$ \\
Hypertension & 399 & $16 \cdot 0$ \\
Obesity & 216 & $8 \cdot 7$ \\
Fe-deficiency anaemia & 166 & $6 \cdot 7$ \\
Hyperparathyroidism & 160 & $6 \cdot 4$ \\
Pregnancy & 30 & $1 \cdot 2$ \\
\hline
\end{tabular}

Table 2 Mean serum 25-hyroxyvitamin D (25(OH)D; ng/ml) in the study population according to gender, age and season of measurement: adult out-patients ( $n$ 2488), Istanbul, Turkey, March 2009-March 2011

\begin{tabular}{llr}
\hline & Mean & SD \\
\hline Overall $(n$ 2488) & $17 \cdot 4$ & $11 \cdot 5$ \\
$\quad$ Females & $17 \cdot 3$ & $11 \cdot 6$ \\
Males & $18 \cdot 1$ & $11 \cdot 2$ \\
$<45$ years of age $(n$ 700) & & \\
Overall & $15 \cdot 9$ & $9 \cdot 8$ \\
Females & $16 \cdot 2$ & $9 \cdot 8$ \\
Males & $14 \cdot 8$ & $10 \cdot 1$ \\
$\geq 45$ years of age $(n$ 1788) & & $12 \cdot 1$ \\
Overall & $18 \cdot 0$ & $12 \cdot 2$ \\
Females & $17 \cdot 8^{\star}$ & $11 \cdot 3$ \\
Males & $19 \cdot 4$ & $11 \cdot 1$ \\
Season of measurement & & $13 \cdot 6$ \\
Summer $(19 \cdot 9 \%)$ & $18 \cdot 6$ & $10 \cdot 2$ \\
Autumn $(18 \cdot 5 \%)$ & $23 \cdot 3$ & $10 \cdot 3$ \\
Winter $(33 \cdot 7 \%)$ & $14 \cdot 6^{\star \star}$ & $16 \cdot 1^{\star \star}$ \\
$\quad$ Spring $(27 \cdot 8 \%)$ & & \\
\hline
\end{tabular}

Mean values were significantly different from those of male patients aged $\geq 45$ years: ${ }^{\star} P<0.05$.

Mean values were significantly different from those obtained during summer and autumn months: ${ }^{\star *} P<0 \cdot 01$. determined that levels obtained in summer and autumn were significantly higher than those in spring and winter $(P<0 \cdot 01$; Table 2 and Fig. 1$)$.

The distribution of the patients according to vitamin D status that is sufficient, insufficient and deficient in the overall study population and in age groups of $<45$ and $\geq 45$ years is shown in Table 3 . Sufficient vitamin D levels were determined only in $9 \cdot 8 \%$ ( $n$ 243) of patients. When evaluated according to age group, the prevalence of vitamin D deficiency was found to be significantly lower in patients aged $<45$ years than in those aged $\geq 45$ years $(P<0 \cdot 05$; Table 3$)$.

When patients who have obesity were considered, their mean $25(\mathrm{OH}) \mathrm{D}$ levels were determined to be significantly lower than in non-obese patients (15.6 (sD $10 \cdot 4) \mathrm{ng} / \mathrm{ml} v \cdot 17 \cdot 6$ (sD $11 \cdot 6) \mathrm{ng} / \mathrm{ml} ; P<0 \cdot 05$ ).

The association between serum 25(OH)D and PTH concentrations in a non-linear regression model revealed that $25(\mathrm{OH}) \mathrm{D}$ concentration of $30 \mathrm{ng} / \mathrm{ml}$ is needed to keep PTH concentration low (Fig. 2).

Levels of $25(\mathrm{OH}) \mathrm{D}(\mathrm{ng} / \mathrm{ml})$ were significantly negatively correlated to serum PTH levels $(r=-0 \cdot 194$; $P<0 \cdot 001)$ while significantly positively correlated to phosphorus $(r=0 \cdot 059 ; P<0 \cdot 01)$ and HDL-C $(r=0 \cdot 070$; $P<0 \cdot 01$ ) levels (Table 4).

\section{Discussion}

Since the major stimulus for PTH secretion is a low level of serum ionized $\mathrm{Ca}$, the $25(\mathrm{OH}) \mathrm{D}$ level that maximally

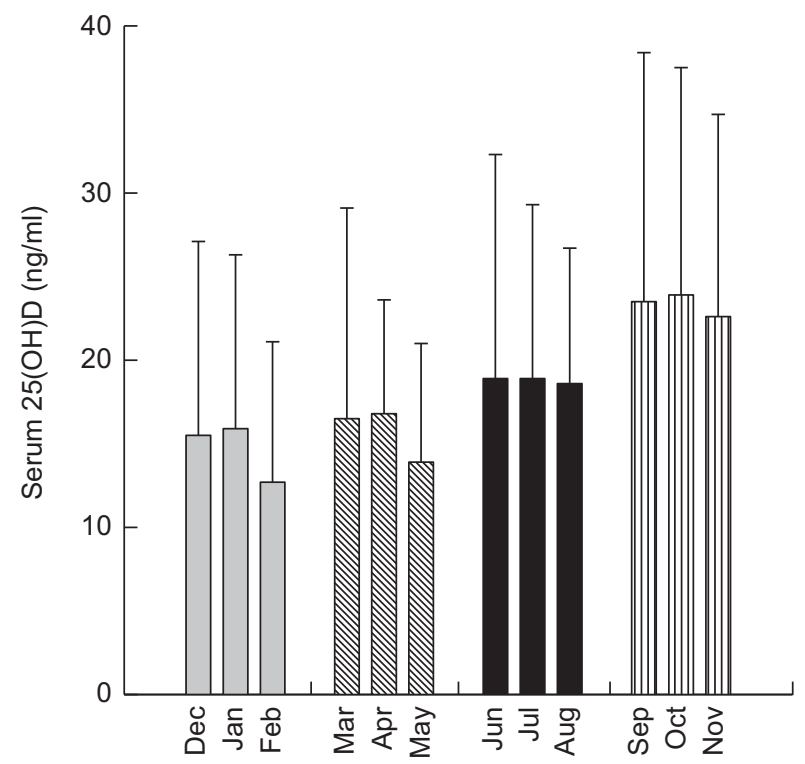

Fig. 1 Serum 25-hyroxyvitamin D (25(OH)D) level according to month/season ( $\square$, winter months; $\mathbb{W}$, spring months;

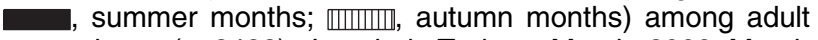
out-patients ( $n$ 2488), Istanbul, Turkey, March 2009-March 2011. Values are means with standard deviations represented by vertical bars 
Table 3 Mean serum 25-hyroxyvitamin D (25(OH)D) levels and classification of vitamin D status (sufficiency, insufficiency, deficiency) in the study population according to age: adult out-patients ( $n$ 2488), Istanbul, Turkey, March 2009-March 2011

\begin{tabular}{|c|c|c|c|c|c|c|c|c|}
\hline & & & \multicolumn{6}{|c|}{ Vitamin D status } \\
\hline & \multicolumn{2}{|c|}{ Serum 25(OH)D (ng/ml) } & \multicolumn{2}{|c|}{ Sufficient (>30 ng/ml) } & \multicolumn{2}{|c|}{ Insufficient (20-30 ng/ml) } & \multicolumn{2}{|c|}{ Deficient $(<20 \mathrm{ng} / \mathrm{ml}$} \\
\hline & Mean & SD & $n$ & $\%$ & $n$ & $\%$ & $n$ & $\%$ \\
\hline Overall ( $n$ 2488) & $17 \cdot 4$ & 11.5 & 243 & $9 \cdot 8$ & 596 & $24 \cdot 0$ & 1649 & $66 \cdot 3$ \\
\hline$<45$ years of age $(n 700)$ & $16 \cdot 0^{\star \star}$ & $9 \cdot 8$ & 53 & $7 \cdot 6$ & 146 & $20 \cdot 8$ & $501^{*}$ & $71 \cdot 5$ \\
\hline$\geq 45$ years of age $(n 1788)$ & $18 \cdot 0$ & $12 \cdot 1$ & 190 & $10 \cdot 6$ & 450 & $25 \cdot 2$ & 1148 & $64 \cdot 2$ \\
\hline
\end{tabular}

Mean values were significantly different from those of patients aged $\geq 45$ years: ${ }^{\star} P<0.05,{ }^{\star \star} P<0.001$.

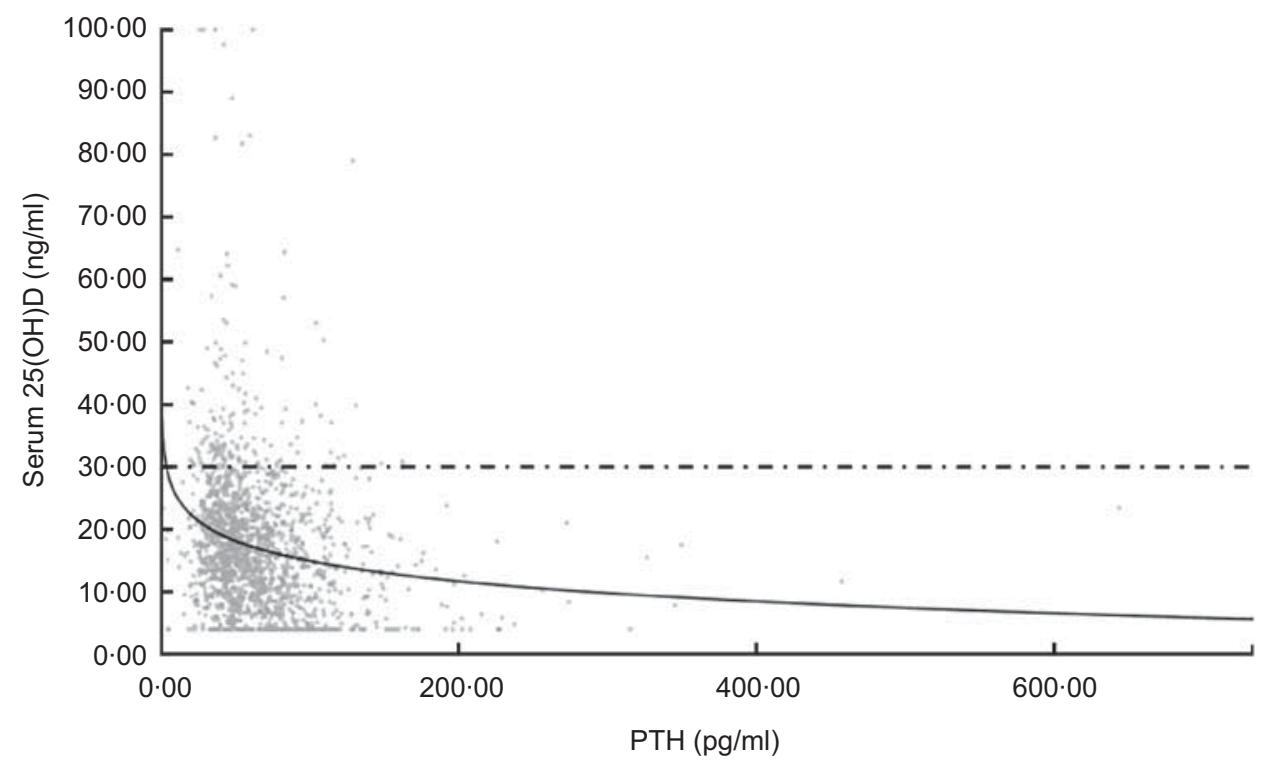

Fig. 2 The association between serum 25-hyroxyvitamin $\mathrm{D}(25(\mathrm{OH}) \mathrm{D})$ and parathyroid hormone (PTH) concentrations in adult out-patients (n 2488), Istanbul, Turkey, March 2009-March 2011. Non-linear regression model with vitamin D as dependent variable and PTH as independent variable $(O$, observed; - , logarithmic fit; $-\cdot-\cdot-, 25(\mathrm{OH}) \mathrm{D}$ concentration needed to keep PTH concentration low). Model summary: $R^{2}=0 \cdot 047, F=77 \cdot 185$, df1 $=1$, df2 $=1579, P=0 \cdot 000$; parameter estimates: constant $=36 \cdot 490, b_{1}=-4 \cdot 680$

suppresses PTH secretion is considered the functional definition of sufficient vitamin $\mathrm{D}$ status. Therefore the rationale behind the selection of $30 \mathrm{ng} / \mathrm{ml}$ as the cut-off value for defining vitamin D sufficiency is the data from multiple cross-sectional examinations concerning the plateau in suppression of PTH when 25(OH)D level reaches approximately $30 \mathrm{ng} / \mathrm{ml}^{(1)}$.

In this respect, similar to what is reported in other studies and confirming that vitamin D deficiency is widespread $^{(8)}$, hypovitaminosis $\mathrm{D}$ was identified to be very common in our study population. Identification of vitamin D deficiency at concentrations associated with severe consequences $^{(4)}$ in $66 \%$ of our study population is notable, especially when the corresponding rates of deficiency reported in the adult population in Europe (7-27\%), South-East Asia, Australia (8-17\%) and the USA $(5 \%)$ are considered ${ }^{(2)}$. Likewise, mean serum $25(\mathrm{OH}) \mathrm{D}$ levels in our male $(18 \cdot 1 \mathrm{ng} / \mathrm{ml} ; 45 \cdot 18 \mathrm{nmol} / \mathrm{l})$ and female $(17 \cdot 3 \mathrm{ng} / \mathrm{ml} ; 43 \cdot 43 \mathrm{nmol} / \mathrm{l})$ patients were lower than overall mean data from the latest US National Health and Nutrition Examination Survey $(62.9 \mathrm{nmol} / 1$ in men; $61.5 \mathrm{nmol} / 1 \mathrm{in}$ women) and most European studies $(53.8 \mathrm{nmol} / 1$ in men; $51.5 \mathrm{nmol} / 1$ in women $)^{(13-15)}$.

Besides, while our observation that 25(OH)D serum levels were higher in summer and autumn than in winter and spring is consistent with previous studies ${ }^{(15-17)}$, vitamin D status identified even in summer and autumn months was still below the optimum in our population. Likewise, similarly, in another study conducted in Turkey, evaluation of 472 patients including osteopenia and osteoporosis patients $(84 \cdot 7 \%)$ and controls $(15 \cdot 3 \%)$ revealed hypovitaminosis $\mathrm{D}(<20 \mathrm{ng} / \mathrm{ml})$ in $52 \cdot 8 \%$ of osteoporosis patients and in $51.6 \%$ of the control group; and indicated that while lowest values of serum vitamin D were obtained in March and highest values in September, overall values were still below the levels reported in other countries ${ }^{(18)}$.

Although some studies have shown higher vitamin D and lower PTH levels in men compared with women 
Table 4 Correlation between serum 25(OH)D and biochemical parameters among adult out-patients ( $n$ 2488), Istanbul, Turkey, March 2009-March 2011

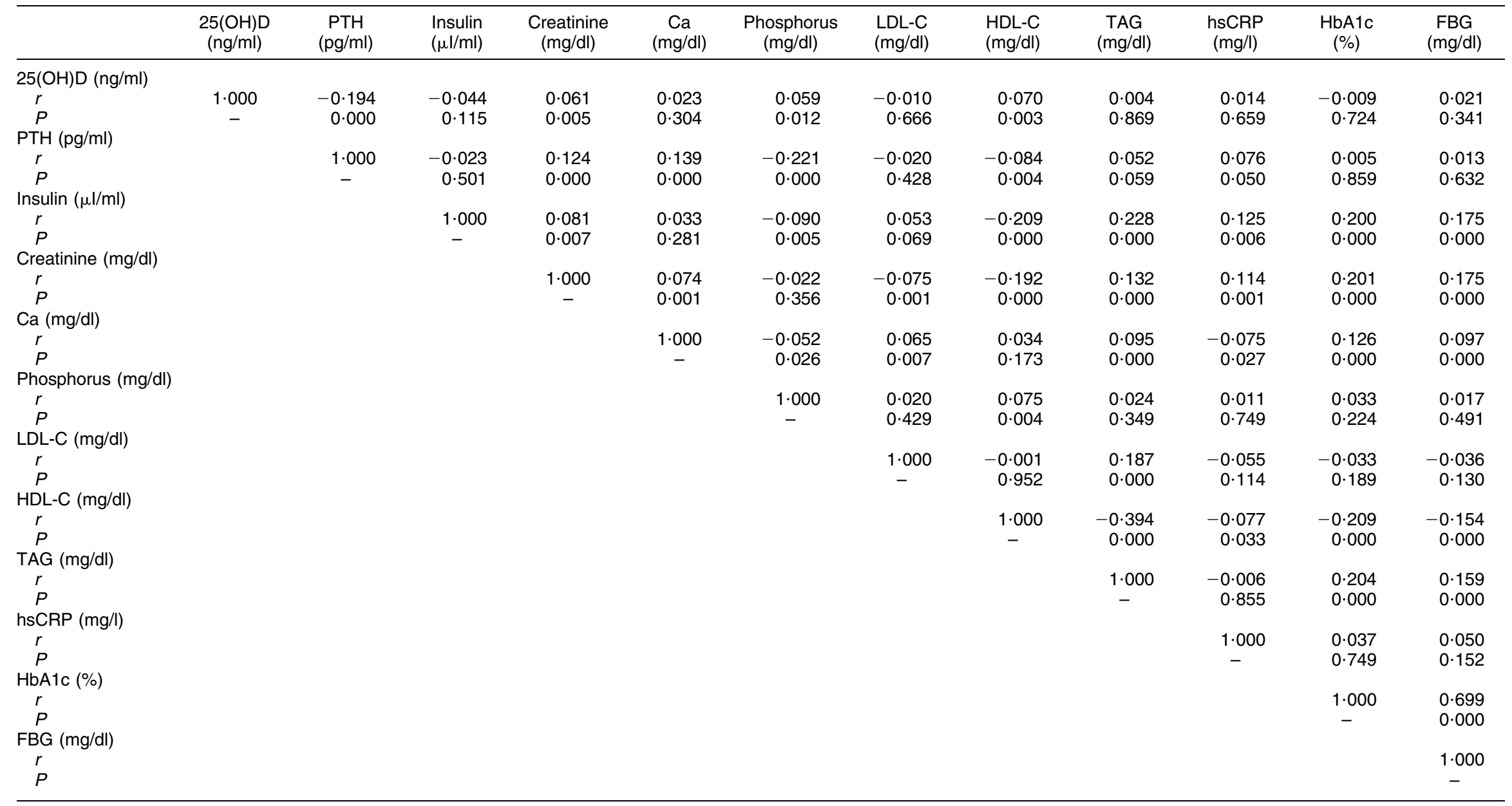

25(OH)D, 25-hdroxyvitamin D; PTH, parathyroid hormone; LDL-C, LDL cholesterol; HDL-C, HDL cholesterol; hsCRP, high-sensitivity C-reactive protein; HbA1c, glycated Hb; FBG, fasting blood glucose. 
throughout the year, this finding was not reported consistently in all studies ${ }^{(5)}$. Accordingly, while there was no gender influence on 25(OH)D levels in the overall population in our study, unlike reported lower values in females than males in the general population ${ }^{(16)}$, identification of lower 25(OH)D levels in female patients older than 45 years of age seems to support the reported tendency of women to have lower values in elderly populations ${ }^{(15)}$.

Moreover, persons with low vitamin D levels were reported to be older ${ }^{(19)}$, more likely to be women, to have higher BMI and less sun exposure, while BMI and female sex were reported to be independently associated with vitamin D insufficiency in the literature ${ }^{(20)}$.

Although 25(OH)D levels were reported to be lower in elderly people based on diminished cutaneous production of vitamin D with ageing, lower sun exposure due to spending little time outdoors and lower $\mathrm{Ca}$ intake in the elderly $^{(5)}$, the frequency of vitamin D deficiency was identified to be much higher in younger patients than in patients aged $\geq 45$ years in our study population, which might be related to more common use of vitamin D supplements in the elderly. Interestingly, supporting the significantly lower 25(OH)D levels in our elderly but not younger female patients when compared with males, the age-related fall in vitamin D level was previously reported not to be the same in both genders and suggested to occur at a younger age in women than men ${ }^{(5,21)}$.

While strong seasonal variation in serum $25(\mathrm{OH}) \mathrm{D}$ with a marked downward shift during the winter months has been reported consistently ${ }^{(22)}$, identification of vitamin D deficiency even in the summer months in our country which has, in most of its geographic regions, sufficient sunshine to maintain adequate vitamin $\mathrm{D}$ status by dermal synthesis ${ }^{(23-25)}$ - seems worth noting. In this vein, similar to studies indicating lower levels of vitamin D in females that mainly reflect lifestyle and dress style ${ }^{(5,26,27)}$, most Turkish women of reproductive age were documented to lack benefit from this source because of their clothing habits ${ }^{(28)}$.

The association of obesity with low 25(OH)D levels in our population is in line with the consistently reported negative correlation between vitamin $\mathrm{D}$ and fat mass in the literature. The inverse $25(\mathrm{OH}) \mathrm{D}$ and obesity relationship is explained by 'trapping' of the vitamin D parent compound, cholecalciferol, in adipose tissue ${ }^{(5,15)}$ as well as due to a difference in sunbathing habits between obese and lean persons while not confirmed in the elderly ${ }^{(29,30)}$.

The significant correlation of $25(\mathrm{OH}) \mathrm{D}$ with HDL-C (positively) and PTH (negatively) levels in our population is important with respect to the consistently reported relationship of vitamin $\mathrm{D}$ and its insufficiencies with greater mortality from chronic $\mathrm{CVD}^{(2)}$, higher incidence of cardiovascular risk factors such as hypertension, obesity, metabolic syndrome and diabetes mellitus type $2^{(2)}$ and higher risk for incident cardiovascular symptoms including angina, coronary insufficiency, myocardial infarction, transient ischaemic attack and stroke ${ }^{(2)}$.

Over the last few years, discussions have focused on determining desirable serum 25(OH)D levels to optimize bone health, using various surrogate markers of vitamin D status, including the relationship between serum 25(OH)D and PTH levels ${ }^{(5)}$. In this regard, the negative correlation of PTH levels to vitamin D levels in our study is consistent with data on the inverse relationship between serum 25(OH)D and PTH levels in other countries $^{(5)}$ as well as a previous study conducted in Turkey with osteopenia and osteoporosis patients ${ }^{(18)}$, while this well-described association was reported to vary across studies and populations ${ }^{(5)}$.

High prevalence of hypovitaminosis D in our population despite inclusion of patients receiving vitamin D supplements supports the statement that the prevalence of vitamin D deficiency remains high even in supplement users, leading $39 \cdot 6 \%$ of supplement users to be vitamin D deficient $(<20 \mathrm{ng} / \mathrm{ml})^{(8)}$. In fact, in correlation to the previously reported ${ }^{(31)}$ increase in circulating $25(\mathrm{OH}) \mathrm{D}$ level of only $1 \mathrm{ng} / \mathrm{ml}$ for every $2.5 \mu \mathrm{g}$ (100 IU) of vitamin $\mathrm{D}_{2}$ or vitamin $\mathrm{D}_{3}$ ingested, our results strengthen the impression ${ }^{(32)}$ that commonly used supplement doses are inadequate to ensure vitamin D nutrition ${ }^{(8)}$.

As a matter of fact, while factors including race, vitamin D intake, sun exposure, adiposity, age and physical activity are known to influence $25(\mathrm{OH}) \mathrm{D}$ levels, most of the individual variation of $25(\mathrm{OH}) \mathrm{D}$ values has been considered difficult to explain, even when all the factors known to influence 25(OH)D concentrations are taken into account ${ }^{(1)}$. Consequently, the duration of vitamin D insufficiency, the responsiveness of the vitamin $\mathrm{D}$ receptor, dietary $\mathrm{Ca}$ intake, and individual $\mathrm{Ca}$ requirements and absorption capacity of the intestines were reported to likely modify the clinical consequences of vitamin D deficiency or insufficiency, which seems difficult to assess on the basis of concentrations of $25(\mathrm{OH}) \mathrm{D}$ alone ${ }^{(1)}$.

Nevertheless, while direct comparison of studies on vitamin $\mathrm{D}$ intake in different parts of the world has been considered difficult due to differences in lifestyle and clothing habits, consumption of traditional foods or supplement intake, combined evidence from all studies clearly indicates that vitamin D insufficiency and Ca malnutrition are common in both genders worldwide, not only in elderly people as previously believed but also in younger adults ${ }^{(2,33)}$.

Besides, based on an increasing incidence of CVD, diabetes, metabolic syndrome and cancer rates in the general population, it seems reasonable to speculate on the relationship among these conditions and the seemingly prevalent finding of vitamin D deficiency in most of countries ${ }^{(34,35)}$. In this respect, consideration of simple and low-cost measures that have the potential to address the problem of vitamin $\mathrm{D}$ inadequacy, including food sources such as fatty fish and fortified foods, skin 
exposure to UV-B from the sun or artificial light sources and vitamin D supplementation, seems crucial ${ }^{(7)}$.

The main limitation of the present study is the inclusion of out-patients suffering from certain diseases likely to indicate vitamin $\mathrm{D}$ status differing from the general population. Second, our findings must be cautiously interpreted based on the lack of supporting variables related to outcome of vitamin D deficiency, such as bone markers or bone parameters, in our study population.

\section{Conclusions}

Our findings indicate vitamin D deficiency to be very common in women and men out-patients living in Istanbul, regardless of age, especially among the obese and during the winter and spring. Identification of vitamin D sufficiency in only $10 \%$ of our population as well as determination of insufficiency even in younger persons and in the summer months seem to emphasize the great risk posed by a myriad of health problems based on the consideration of vitamin D deficiency as a long-standing condition, rather than a recent occurrence $^{(8)}$. In this regard, the enormous opportunity to improve individual and public health by identification and appropriate correction of vitamin D status in individuals and populations, beginning from pregnancy and/or early childhood, must be taken into consideration by the medical community. Future studies concerning vitamin D insufficiency in relation to the potential multitude of health sequelae in the general population are required to establish population means and definitions of deficiencies, as well as to translate the need for change evident from emerging research into day-to-day clinical implementation.

\section{Acknowledgements}

Source of funding: This research received no specific grant from any funding agency in the public, commercial or notfor-profit sectors. Conflicts of interest: The authors declare that they have no conflict of interest. Authors' contributions: O.C. designed the study, worked in all stages of data collection and analysis. H.P. and A.D.U. made substantial contributions to conception and design. R.E. and N.G.D. made substantial contributions to performing the statistical analysis. All authors read and approved the final manuscript. Acknowledgements: The authors would like to thank Dr Feyza Dinc and Dr Hacer Eroglu, Lab Specialists of the Department of Biochemistry, for helpful evaluations and discussions of the biochemical results.

\section{References}

1. Thacher TD \& Clarke BL (2011) Vitamin D insufficiency. Mayo Clin Proc 86, 50-60.

2. Peterlik M, Boonen S, Cross HS et al. (2009) Vitamin D and calcium insufficiency-related chronic diseases: an emerging world-wide public health problem. Int J Environ Res Public Health 6, 2585-2607.

3. Mithal A, Wahl DA, Bonjour JP et al. (2009) Global vitamin D status and determinants of hypovitaminosis D. Osteoporos Int 20, 1807-1820.

4. Holick M (2007) Vitamin D deficiency. N Engl J Med 357, 266-281.

5. Arabi A, Baddoura R, El-Rassi R et al. (2010) Age but not gender modulates the relationship between PTH and vitamin D. Bone 47, 408-412.

6. Bordelon P, Ghetu MV \& Langan RC (2009) Recognition and management of vitamin D deficiency. Am Fam Physician 80, 841-846.

7. Genuis SJ, Schwalfenberg GK, Hiltz MN et al. (2009) Vitamin D status of clinical practice populations at higher latitudes: analysis and applications. Int J Environ Res Public Health 6, 151-173.

8. Orwoll E, Nielson CM, Marshall LM et al. (2009; Osteoporotic Fractures in Men (MrOS) Study Group Vitamin D deficiency in older men. J Clin Endocrinol Metab 94, 1214-1222.

9. Holick MF (2005) The vitamin D epidemic and its health consequences. J Nutr 135, 2739-2748.

10. Cantorna MT (2006) Vitamin D and its role in immunology: multiple sclerosis, and inflammatory bowel disease. Prog Biophys Mol Biol 92, 60-64.

11. Bischoff-Ferrari HA (2008) Optimal serum 25-hydroxyvitamin $\mathrm{D}$ levels for multiple health outcomes. Adv Exp Med Biol 624, 55-71.

12. World Health Organization (2000) Obesity: Preventing and Managing the Global Epidemic. Report of a WHO Consultation. WHO Technical Report Series no. 894. Geneva: WHO.

13. Looker AC, Pfeiffer CM, Lacher DA et al. (2008) Serum 25-OHD status of the US population: 1988-1994 of 2000-2004. Am J Clin Nutr 88, 1519-1527.

14. Hirani V, Mosdøl A \& Mishra G (2009) Predictors of 25-hydroxyvitamin D status among adults in two British national surveys. Br J Nutr 101, 760-764.

15. Brock K, Huang WY, Fraser DR et al. (2010) Low vitamin D status is associated with physical inactivity, obesity and low vitamin D intake in a large US sample of healthy middleaged men and women. J Steroid Biochem Mol Biol 121, 462-466.

16. International Agency for Research on Cancer (2008) Vitamin D and Cancer. IARC Working Group Report no. 5. Lyon: IARC.

17. Hagenau T, Vest R, Gissel TN et al. (2009) Global vitamin D levels in relation to age, gender, skin pigmentation and latitude: an ecologic meta-regression analysis. Osteoporos Int 20, 133-140.

18. Yanik B, Geler D, Gok H et al. (2005) Serum vitamin D levels in patients appealed to osteoporosis outpatient clinic. Fiziksel Tip 8, 7-11.

19. Ramel A, Jonsson PV, Bjornsson S et al. (2009) Vitamin D deficiency and nutritional status in elderly hospitalized subjects in Iceland. Public Health Nutr 12, 1001-1005.

20. Ding C, Cicuttini F, Parameswaran V et al. (2009) Serum levels of vitamin $\mathrm{D}$, sunlight exposure, and knee cartilage loss in older adults: the Tasmanian older adult cohort study. Arthritis Rheum 60, 1381-1389.

21. Maggio D, Cherubini A, Lauretani F et al. (2005) 25(OH)D serum levels decline with age earlier in women than in men and less efficiently prevent compensatory hyperparathyroidism in older adults. J Gerontol A Biol Sci Med Sci 60, 1414-1419.

22. Pedersen JI (2008) Vitamin D requirement and setting recommendation levels - current Nordic view. Nutr Rev 66, Suppl. 2, 165-169. 
23. Ergür AT, Berberoğlu M, Atasay B et al. (2009) Vitamin D deficiency in Turkish mothers and their neonates and in women of reproductive age. J Clin Res Pediatr Endocrinol 1, 266-269.

24. Hekimsoy Z, Dinç G, Kafesçiler S et al. (2010) Vitamin D status among adults in the Aegean region of Turkey. BMC Public Health 10, 782.

25. Atli T, Gullu S, Uysal AR et al. (2005) The prevalence of Vitamin D deficiency and effects of ultraviolet light on vitamin D levels in elderly Turkish population. Arch Gerontol Geriatr 40, 53-60.

26. Salamoun M, Kizirian A, Tannous R et al. (2005) Low calcium and vitamin D intake in healthy children and adolescents and their correlates. Eur J Clin Nutr 59, 177-184.

27. Arabi A, Baddoura R, Awada H et al. (2006) Hypovitaminosis D osteopathy: is it mediated through PTH, lean mass, or is it a direct effect? Bone 39, 268-275.

28. Andiran N, Yordam N \& Özon A (2002) Risk factors for vitamin $\mathrm{D}$ deficiency in breast fed newborns and their mothers. Nutrition 18, 47-50.

29. Harris S \& Dawson-Hughes B (2007) Reduced sun exposure does not explain the inverse association of 25-hydroxyvitamin D with percent body fat in older adults. J Clin Endocrinol Metab 92, 3155-3157.

30. Kull M, Kallikorm R \& Lember L (2009) Body mass index determines sunbathing habits: implications on vitamin D levels. Int Med J 39, 256-258.

31. Holick MF, Biancuzzo RM, Chen TC et al. (2008) Vitamin $\mathrm{D}_{2}$ is as effective as vitamin $\mathrm{D}_{3}$ in maintaining circulating concentrations of 25-hydroxyvitamin D. J Clin Endocrinol Metab 93, 677-681.

32. Vieth R, Bischoff-Ferrari H, Boucher BJ et al. (2007) The urgent need to recommend an intake of vitamin $\mathrm{D}$ that is effective. Am J Clin Nutr 85, 649-650.

33. Bolek-Berquist J, Elliott ME, Gangnon RE et al. (2009) Use of a questionnaire to assess vitamin D status in young adults. Public Health Nutr 12, 236-243.

34. Scragg R (2011) Vitamin D and public health: an overview of recent research on common diseases and mortality in adulthood. Public Health Nutr 14, 1515-1532.

35. Johal M \& Levin A (2009) Vitamin D and parathyroid hormone in general populations: understandings in 2009 and applications to chronic kidney disease. Clin J Am Soc Nephrol 4, 1508-1514. 